\title{
Risk, Business Cycles and Financial Crises: Evidence from Islamic and Conventional Stocks
}

(Risiko, Kitaran Perniagaan dan Krisis Kewangan: Bukti daripada Saham Islam dan Konvensional)

\author{
Lain-Tze Tee
}

Si-Roei Kew

(Faculty of Economics and Management, Universiti Kebangsaan Malaysia)

\begin{abstract}
This study examines whether business cycles and financial crises affect the risk of Islamic stocks compared to conventional stocks in Malaysia for the period 1997 to 2016. The findings conclude that business cycles play a crucial role in affecting stock risk. Specifically, stock risk tends to be higher during the economic contraction than during economic expansion for Islamic, conventional and all stocks. We further test whether Asian and Global financial crises exacerbate stock risk. The results document that the level of stock risk increases during financial crises. Moreover, we find that the impact of economic contraction and financial crises on increasing stock risk remain significant after controlling for various variables known to have effect on risks. In addition, we discover that the risk of Islamic stock is lower compared to those of conventional and all stocks during the economic contraction and financial crises. This recommends the diversification advantage and investment opportunity of the Islamic stocks during the periods of financial turbulence. The findings offer important insights to investors who are considering Islamic or conventional stocks as potential investment and to policymakers in evaluating stock risk in different economic states.
\end{abstract}

Keywords: Islamic and conventional stocks; stock risk; business cycles; economic expansion and contraction; financial crises

ABSTRAK

Kajian ini dijalankan untuk mengkaji sama ada kitaran perniagaan dan krisis kewangan memberi kesan kepada risiko saham Islam berbanding saham konvensional di Malaysia dari tahun 1997 ke 2016. Penemuan menyimpulkan bahawa kitaran perniagaan memainkan peranan penting dalam mempengaruhi risiko. Khususnya, risiko adalah lebih tinggi semasa pengecutan ekonomi berbanding pengembangan ekonomi bagi semua saham, saham Islam dan saham konvensional. Selain itu, kami mengkaji sama ada krisis kewangan Asian dan global memberi kesan terhadap risiko saham. Kami mendapati bahawa tahap risiko meningkat semasa krisis kewangan. Kami juga mendapati risiko saham kekal meningkat semasa pengecutan ekonomi dan krisis kewangan selepas merangkumi pembolehubah kawalan yang mempunyai kesan terhadap risiko saham. Kami mendapati bahawa saham Islam adalah kurang berisiko berbanding saham konvensional dan semua saham semasa pengecutan ekonomi dan krisis kewangan. Ini mencadangkan bahawa saham Islam memberikan kebaikan diversifikasi dan peluang pelaburan dalam tempoh pergolakan kewangan. Penemuan ini memberi implikasi penting kepada pelabur yang sedang mempertimbangkan saham Islam atau konvensional sebagai pelaburan yang berpotensi dan kepada pelaksana dasar untuk menilai risiko saham dalam keadaan ekonomi yang berbeza. 
Kata kunci: Saham Islam dan konvensional; risiko saham; kitaran perniagaan; pengembangan dan pengecutan ekonomi; krisis kewangan

\section{INTRODUCTION}

While Malaysia is acknowledged as an Islamic financial market across the world, the research on whether business cycles and financial crises affect the risk of Islamic stocks remains unexplored in the Malaysian context. Islamic equity investments are popular among investors. Muslim investors tend to invest in firms that are compliant with Islamic laws. Investments in firms gaining notable profits from conventional financial services, gambling, entertainment, products made from liquor, pork and tobacco, and other business activities that do not compliant with Islamic laws are not permitted in Islam. Further, firms must meet specific targets for certain financial ratios, signifying that firms with sinful interest income and intolerable debt burdens are unsuited for Islamic investment purposes.

This study examines risk for Islamic and conventional stocks. The findings of whether being shariah-compliant firms would decrease stock risk are important for firms which consider shifting to be Shariah-compliant equities and for investors who consider investing Islamic or conventional stocks. Earlier studies indicate that the basic Islamic principles that oversee Islamic stocks explain the variability in the risk of Islamic stocks and conventional stocks. Al-Zoubi and Maghyereh (2007) find that Islamic stocks are less risky than conventional stocks in the United States market. The findings may be explained by the principles of profit and loss sharing in Islamic finance where banks share the profits and bear loses (Mudarabah) or share both profits and losses (Musharaka) with companies. Therefore, Islamic stock returns are less volatile compared to their conventional counterparts due to their distinct characteristics.

Consistent with Al-Zoubi and Maghyereh (2007), Dharani and Natarajan (2011) find that Islamic stocks have lower level of risk than conventional stocks in the Indian stock market. Ahmed and Farooq (2018) document that portfolios with the highest level of Shariah compliances exhibit lower volatility than the least Shariah compliant and market portfolios for the seven Middle East and North Africa (MENA) countries. However, Charles, Darne and Pop (2015) find contradictory results that Dow Jones Islamic Indices are more risky than conventional indices due to the lack of diversification in the Islamic indices. There is no conclusive finding about the risk of Islamic stocks and conventional stocks. This study adds to the literature on the risk of Islamic and conventional stocks in the emerging market context.

Past studies find that business cycles have impact on stock risk (Choudhry, Papadimitriou \& Shabi 2016; Mele 2008; Schwert 1989). The authors provide evidence that stock volatility is higher during recessions. However, these studies only focus on conventional stocks. Moreover, financial crises create disturbances to financial markets. Previous literature (Ho et al. 2014; Alam \& Rajjaque 2010) examines the effect of financial crises on stock performance and finds that Islamic stocks outperform conventional stocks and overall market. However, existing literature exploring the effects of both business cycles and financial crises on the risk of Islamic stocks and conventional stocks is limited. This study fills this research gap.

Macroeconomic conditions, particularly business cycles, in Malaysia are different from the economic states in other countries. According to Rand and Tarp (2002), business cycles vary among developing countries and the business cycles in developing countries are also noticeably diverse from those in developed countries. Moreover, Kose, Otrok and Prasad (2012) provide evidence that there is a limited association between business cycles in 
developing countries and developed countries. Thus, the impact of economic states on stock risk in Malaysia may be dissimilar as compared to other countries. Moreover, risk of Islamic stocks may be different from the risk of conventional during economic downturns and financial crises. Islamic stocks have low leverage thanks to the Shariah screening criteria. Islamic stocks exclude many interest-based financial institution stocks which suffer from significant decline in stock prices during financial crises. In addition, Islamic markets are prohibited from holding sub-prime mortgage securities and derivatives. These characteristics result in Islamic stocks tend to be more stable and less risky compared to conventional stocks during market downturn and financial crises (Akhtar \& Jahromi 2017; Dewandaru et al. 2015). Taken together, the growing demand of Islamic equity investments, different stock characteristics and diverse business cycles motivate us to examine the link between business cycles, financial crises and the risk of Islamic and conventional stocks in the Malaysian setting.

Our paper contributes to the current literature on stock risk and business cycles in several ways. First, this study examines whether business cycles, particularly economic expansion and economic contraction, and financial crises affect the level of stock risk in Malaysia. Second, while most of the existing studies focus only on conventional and all stocks, we explore the effect of business cycles and financial crises on the risk of Islamic, conventional and all stocks in the Malaysian market. Third, unlike most studies that employ aggregate Islamic stock indices, we use individual Islamic stocks and conventional stocks. Finally, this paper includes a long study period from 1997 to 2016, proving a comprehensive dataset to judge whether the business cycles and financial crises increase the stock risk.

The rest of the paper proceeds as follows. Section 2 reviews the literature. Sections 3 and 4 describe the data and discuss the methodology. Section 5 reports the findings and finally, Section 6 concludes the paper.

\section{LITERATURE REVIEW}

Previous literature shows the effect of business cycles on stock risk. Schwert (1989) documents a spike in the level of stock return volatility during recession in the United States (US). Mele (2008) observes a high degree of stock volatility during recession than during expansion in the US, suggesting that stock prices react to changes in economic conditions. Consistent with previous studies, Choudhry et al. (2016) find significant link between business cycle and stock market volatility in Canada and in the United Kingdom (UK).

On the other hand, empirical studies document the impact of financial crises on the stock market. Schwert (1989) find that the volatility of stock return spikes around major financial crises in the US. Extending the countries of study, Schwert (2011) affirms that financial crises influence the volatility of stock markets. The findings show a higher degree of stock return volatility during financial crises in the US, the UK and Japan. Additionally, Athukoralalage, Valadkhani and O'Brien (2010) show the Asian and global financial crisis significantly increase stock risk across Australia, Singapore, the UK and the US. However, this study examines the conventional stock market indices.

There is substantial literature documenting that the performance of Islamic stocks is greater than the conventional stocks during the financial crises. For instances, Alam and Rajjaque (2010) show that Islamic stocks have better performance than the overall market during credit crunch in the European stock market. Jawadi, Jawadi and Louhichi (2014) document evidence that the influence of global financial crisis on Islamic finance in Europe, USA and the world. In line with the findings of Alam and Rajjaque (2010), the authors find that the impact of financial crises is less significant on Islamic indices' returns than the 
conventional indices' returns. This may indicates the diversification benefits and investment opportunities of the Islamic stocks during the financial turbulence periods.

Ho et al. (2014) report Islamic stock indices outperform conventional stock indices during the global financial crisis. Additionally, the authors find that risks for both conventional and Islamic indices are higher in the crisis times. Nevertheless, risk on Islamic equity investments is lesser than those of their conventional counterparts in the international markets. Nonetheless, Miniaoui, Syani and Chaibi (2015) show inconsistent findings that the Islamic indices of the Gulf Cooperation Council (GCC) countries do not exhibit lower volatility compared to conventional indices during the financial crisis, indicating that GCC Islamic indices have comparable risk profile as conventional counterparts.

Further, Ahmed and Farooq (2018) examine whether the degree of Shariah compliance influence stock volatility before and after financial crisis. They find that market portfolios, the most and the least Shariah compliant portfolios increase volatility after the financial crisis. However, the most Shariah compliant portfolios are less volatile compared to the least Shariah compliant and market portfolios.

Akhtar and Jahromi (2017) study the effect of global financial crisis on conventional and Islamic and stock and bond indices in eight non-Islamic and 11 Islamic countries. The authors show that during the global financial crisis, Islamic stocks enjoy the benefits of stability and risk reduction. The results are attributable to Islamic markets are prohibited from holding sub-prime mortgage securities and derivatives.

Based on the previous literature, it is expected that economic contraction and financial crises increase stock risk. Nevertheless, compared to conventional and all stocks, Islamic stocks are expected to have lower level of risk.

\section{DATA}

We retrieve stock price for all individual stocks in Malaysia, Morgan Stanley Capital International (MSCI) world stock price index, Brent crude oil spot price, foreign exchange rate of the US dollar to Malaysian ringgit, Malaysian consumer price indices and Malaysian industrial production from DataStream beginning 1997 to 2016. To diminish potential survivorship bias, we use all listed and delisted stocks.

The stocks are categorised into Islamic and conventional stocks using the list of Shariahcompliant securities provided by the Shariah Advisory Council of the Securities Commission Malaysia since 1997 through 2016. Specifically, Shariah-compliant or Islamic stocks are stocks in which companies' fundamental activities follow the Islamic principles. For examples, no financial activities based on interest (riba), gambling (maisir), pork and porkrelated activities, liquor and liquor-related activities, non-halal food and beverages, tobacco and tobacco-related activities and other activities deemed non-compliant according to Shariah (Securities Commission Malaysia 2016). The Shariah Advisory Council of the Securities Commission Malaysia updates the list of Shariah-compliant securities twice a year. We thus rebalance the Islamic and conventional portfolio semi-annually. The final sample consists of a total of 1,283 listed and delisted stocks. There are 751 stocks that were always Shariah compliant, 426 stocks that changed the status between Shariah complaint and Shariah noncomplaint and 106 stocks that were always Shariah non-complaint.

Data on the periods of contraction and expansion in the level of the Malaysian economic activities is obtained from the Department of Statistics, Malaysia. Particularly, the economic contraction is the period which is measured from the peak to the trough of the business cycles, while the expansion is measured from the trough to the peak of the business cycles. According to Department of Statistics, Malaysia (2017), the peak periods in Malaysia are 
December 1997, February 2001 and January 2008 while the trough periods are November 1998, February 2002 and March 2009.

\section{METHODOLOGY}

We calculate the time series of return as the log of price relatives times 100 , that is, $R_{t}=$ $\ln \left(P_{t} / P_{t-1}\right) \times 100$, where $P_{t}$ is the closing stock price in week $t$, and $P_{t-1}$ is the closing stock price in the previous week $t$.

Following Low, Tee and Kew (2015), we measure risk $\left(\sigma_{i}\right)$ as the volatility of stock return. Specifically, it is computed as the standard deviation of the return series every month. Standard deviation of returns is a commonly referenced risk measure and it measures deviations from the mean value as follows:

$$
\sigma_{i}=\sqrt{\left[\left(R_{i}-\hat{x}_{i}\right)^{2}\right]}
$$

where $R_{i}$ and $\hat{x}_{i}$ are returns and mean returns on $i$, respectively. $i$ is being either Islamic, conventional or all stocks. If standard deviation is high, it implies the magnitude of stock price fluctuation is high. In contrast, low standard deviation reflects the volatility of stock price is low.

Similar to the methodology of Cooper, Gutierrez and Hameed (2004) and Kew and Tee (2018), we regress risk on the dummy variables of business cycles with no intercept to investigate whether the risk is equal to zero in each business cycle, respectively. The regression model is:

$$
\text { risk }_{t}=\beta_{1} \text { contraction }_{t}+\beta_{2} \text { expansion }_{t}+\varepsilon_{t}
$$

where risk $k_{t}$ is the stock risk in month $t, \beta$ is coefficient and $\varepsilon$ is the error term. The independent variables are business cycle dummy variables. Contraction takes the value of one if economy contracts and zero otherwise. On the other hand, expansion takes the value of one if the economy expands and zero otherwise.

To test if the risk during the economic contraction and economic expansion are equal, we regress risk on the dummy variable of economic contraction and an intercept. The regression model is:

$$
\operatorname{risk}_{t}=\alpha_{t}+\theta \text { contraction }_{t}+\varepsilon_{t}
$$

The intercept, $\alpha$ implies risk during the economic expansion. $\theta$ is the difference between stock risk during the economic contraction and economic expansion. These approaches maintain the full time-series of risk and hence generate reliable standard error estimates.

Further, we examine whether the effect of business cycles on stock risk remain significant after controlling for variables known to affect stock risk as shown in the Equation (4).

$$
\text { risk }_{t}=\alpha_{t}+\theta_{1} \text { contraction }_{t}+\theta_{2} \text { wrisk }_{t}+\theta_{3} \text { oil }_{t}+\theta_{4} f x_{t}+\theta_{5} \text { inf }_{t}+\theta_{6} i p_{t}+\varepsilon_{t}
$$

We select the control variables following Low et al. (2015). We control for world stock market risk (wrisk), as measured by the standard deviation of the return on MSCI world stock index. We also control for crude oil price changes (oil), foreign exchange rate changes (fx), inflation rates (inf) and industrial production growth rates (ip). OIL is the percentage changes in the monthly Brent crude oil price. FX is the percentage changes in monthly US dollar to 
Malaysian ringgit. INF is the percentage changes in the Malaysian consumer price indices and IP is the percentage changes in the Malaysian industrial production. We run the regressions with Newey and West's (1987) heteroscedasticity and autocorrelation consistent (HAC) robust standard errors.

In addition, to explore whether stock risk is influenced by financial crises, we replace the business cycle dummy variables with the financial crises dummy variables. The regression models are:

$$
\begin{aligned}
& \operatorname{risk}_{t}=\beta_{1} \text { financial crises }_{t}+\beta_{2} \text { nonfinancialcrisis } \\
& t
\end{aligned}
$$

The dummy variable for financial crises equals to one for the occurrences of the Asian financial crisis from July 1997 to August 1998 and the global financial crisis from September 2008 to March 2009, and zero otherwise. The dummy variable for nonfinancial crises equals to one for the non-occurrence of the financial crises, and zero otherwise. The financial crises and non-financial crises periods reflect economic downturns and upturns, respectively. The intercept, $\alpha$ denotes stock risk during the non-financial crises period. $\theta$ refers to the difference between stock risk during the periods of financial crises and non-financial crises.

Moreover, we test whether the relationship between financial crises and stock risk remain significant after including control variables. The regression model is:

$$
\text { risk }_{t}=\alpha_{t}+\theta_{1} \text { finanial crises }_{t}+\theta_{2} \text { wrisk }_{t}+\theta_{3} \text { oil }_{t}+\theta_{4} f x_{t}+\theta_{5} \text { inf }_{t}+\theta_{6} i_{t}+\varepsilon_{t}
$$

We also add both economic contraction and financial crises variables in the same regression as shown in Equation (8) to explore whether both variables have impact on increasing stock risk after controlling for variables known to affect stock risk.

$$
\begin{aligned}
\text { risk }_{t}= & \alpha_{t}+\theta_{1} \text { contraction }_{t}+\theta_{2} \text { finanial crises }_{t}+\theta_{3} \text { wrisk }_{t}+\theta_{4} \text { oil }_{t}+\theta_{5} f_{t}+ \\
& \theta_{6} \text { inf }_{t}+\theta_{7} \text { ip }_{t}+\varepsilon_{t}
\end{aligned}
$$

\section{FINDINGS}

\section{DESCRIPTIVE STATISTICS}

Table 1 presents the summary statistics of risk for all, Islamic and conventional stocks over the full sample period from 1997 to 2016 . We notice that the average risk is higher for all and conventional stocks than for the Islamic stocks. On average, Islamic stocks have the lowest risk (1.919\%), followed by all stocks (1.997\%) and the conventional stocks $(2.263 \%)$.

TABLE 1. Descriptive statistics of risk for all, Islamic and conventional stocks

\begin{tabular}{llll}
\hline & All stocks & Islamic stocks & Conventional stocks \\
\hline Mean & $1.997^{* * *}$ & $1.919^{* * *}$ & $2.263^{* * *}$ \\
& $(9.506)$ & $(9.693)$ & $(9.742)$ \\
Median & 1.424 & 1.432 & 1.654 \\
Standard deviation & 1.816 & 1.699 & 2.051 \\
Skewness & 2.429 & 2.534 & 2.544 \\
\hline
\end{tabular}

Note: $* * *$ indicates coefficient is significant at the $1 \%$ level. $t$-statistics are in parentheses. 
These results provide an indication that the volatility of Islamic stock return is lower compared to the volatility of conventional and all stock return. The results support the notion of Securities Commission Malaysia (2018) that Islamic capital market is restricted from activities forbidden by the religion of Islam such as usury (riba), gambling (maisir) and excessive risk-taking (gharar). In addition, it promotes risk-sharing and ethical investment and therefore, Islamic stocks are exposed to less uncertainty compared to conventional stocks. Our findings are in line with the findings of Ahmed and Farooq (2018) who document that portfolios with the highest level of Shariah compliances exhibit lower volatility than the least Shariah compliant and market portfolios.

\section{RISK AND BUSINESS CYCLES}

Table 2 reports the findings of the relationship between risk and business cycles. Unsurprisingly, the risk for all stocks escalates from 1.997 to 3.440 and is statistically different from zero during the economic contraction. The risk, however, reduces significantly from 1.997 to 1.732 as the economy expands. When testing for the equality of the risk across economic contraction and expansion, all stocks have statistically 1.708 higher risks during economic contraction than during economic expansion. Hence, the business cycle is important in influencing the volatility of stocks.

TABLE 2. Risk and business cycles

\begin{tabular}{llll}
\hline & All stocks & Islamic stocks & Conventional stocks \\
\hline Economic contraction & 3.440 & 3.223 & 3.960 \\
& $(5.792)^{* * *}$ & $(5.947)^{* * * *}$ & $(5.985)^{* * *}$ \\
Economic expansion & 1.732 & 1.680 & 1.952 \\
& $(9.700)^{* * *}$ & $(9.951)^{* * *}$ & $(9.997)^{* * *}$ \\
Test for equality & & & \\
Contraction - Expansion $=0$ & 1.708 & 1.544 & 2.007 \\
& $(2.909)^{* * *}$ & $(2.920)^{* * *}$ & $(3.040)^{* * *}$ \\
\hline
\end{tabular}

Note: *** indicates coefficient is significant at the $1 \%$ level. $t$-statistics are in parentheses.

When splitting the sample into Islamic stocks and conventional stocks, we confirm the results that risk is greater during the economic contraction than the expansion for both Islamic and conventional stocks. However, it is noticeable that Islamic stocks (3.223) are exposed to lower uncertainty compared to conventional stocks (3.960) during economic downturn. In addition, in times of economic expansion, Islamic stocks (1.680) are less volatile relative to conventional stocks (1.952). The risk differences between bad and good economic states are found to be significant for Islamic and conventional stocks. This implies that Islamic stocks are less risky during economic downturn.

The findings are parallel with those of Mele (2008) and Schwert (1989), implying that stock prices become more volatile during economic downturn. The results may be due to economic contraction intensifies the uncertainty about the process of generating future cash flows and discount rate (Schwert 1989). Also, risk premiums are more volatile and result in stock prices respond greatly to changes in economic conditions especially during the recession (Mele 2008). 
TABLE 3. Risk, business cycles and control variables

\begin{tabular}{|c|c|c|c|c|c|c|}
\hline \multirow[b]{2}{*}{ Constant } & \multicolumn{2}{|c|}{ All stocks } & \multicolumn{2}{|c|}{ Islamic stocks } & \multicolumn{2}{|c|}{ Conventional stocks } \\
\hline & $\begin{array}{l}1.732 * * * \\
(9.700)\end{array}$ & $\begin{array}{l}1.341^{* * *} \\
(5.199)\end{array}$ & $\begin{array}{l}1.680 * * * \\
(9.951)\end{array}$ & $\begin{array}{l}1.325 * * * \\
(5.676)\end{array}$ & $\begin{array}{l}1.952 * * * \\
(9.997)\end{array}$ & $\begin{array}{l}1.512 * * * \\
(5.268)\end{array}$ \\
\hline Contraction & $\begin{array}{l}1.708 * * * \\
(2.909)\end{array}$ & $\begin{array}{l}1.632^{* * * *} \\
(2.965)\end{array}$ & $\begin{array}{l}1.544 * * * \\
(2.920)\end{array}$ & $\begin{array}{l}1.462 * * * \\
(2.944)\end{array}$ & $\begin{array}{l}2.007 * * * \\
(3.040)\end{array}$ & $\begin{array}{l}1.932 * * * \\
(3.126)\end{array}$ \\
\hline World market risk & & $\begin{array}{l}0.161^{*} \\
(1.663)\end{array}$ & & $\begin{array}{l}0.139 \\
(1.547)\end{array}$ & & $\begin{array}{l}0.182^{*} \\
(1.761)\end{array}$ \\
\hline Crude oil price & & $\begin{array}{l}0.011 \\
(0.975)\end{array}$ & & $\begin{array}{l}0.008 \\
(0.763)\end{array}$ & & $\begin{array}{l}0.015 \\
(1.195)\end{array}$ \\
\hline Exchange rate & & $\begin{array}{l}0.035 \\
(0.334)\end{array}$ & & $\begin{array}{l}0.074 \\
(0.797)\end{array}$ & & $\begin{array}{l}-0.014 \\
(-0.117)\end{array}$ \\
\hline Inflation & & $\begin{array}{l}0.250 \\
(0.384)\end{array}$ & & $\begin{array}{l}0.259 \\
(0.408)\end{array}$ & & $\begin{array}{l}0.334 \\
(0.493)\end{array}$ \\
\hline Industrial production & & $\begin{array}{l}0.016 \\
(0.643)\end{array}$ & & $\begin{array}{l}0.015 \\
(0.594)\end{array}$ & & $\begin{array}{l}0.014 \\
(0.579)\end{array}$ \\
\hline Adjusted R-squared & 0.112 & 0.117 & 0.105 & 0.118 & 0.122 & 0.128 \\
\hline F-statistic & $31.141 * * *$ & $6.270^{* * *}$ & $28.861 * * *$ & $6.318 * * *$ & $34.100 * * *$ & $6.829 * * *$ \\
\hline
\end{tabular}

Note: $* * *, * *$ and $*$ indicate coefficient is significant at the $1 \%, 5 \%$ and $10 \%$ levels. $t$-statistics are in parentheses.

Table 3 reports the regression results of risk on business cycles where columns 2, 4 and 6 estimate a bivariate regression for all, Islamic and conventional stocks, respectively. Columns 3,5 and 7 add the control variables for all, Islamic and conventional stocks, respectively. In the bivariate regression, the contraction variable is all positive and significantly related to risk, suggesting that economic contraction increases stock risk for all, Islamic and conventional stocks. The results of high risk during economic contraction remain statistically significant after controlling for world stock market risk, crude oil price changes, exchange rate changes, inflation rate and industrial production growth. The findings also show that Islamic stocks have the lowest risk during economic contraction, followed by all stocks and conventional stocks after incorporating control variables.

\section{RISK AND FINANCIAL CRISES}

Then, to examine the relationship between financial crises and stock risk, we replace the periods of economic contraction and expansion with the periods of the occurrence of financial crises and non-financial crises. The risk during the periods of financial crises and non-financial crises for all, Islamic and conventional stocks are reported in Table 4.

TABLE 4. Risk and financial crises

\begin{tabular}{llll}
\hline & All stocks & Islamic stocks & Conventional stocks \\
\hline Financial crises & 4.829 & 4.643 & 5.337 \\
& $(4.743)^{* * *}$ & $(4.402)^{* * *}$ & $(5.252)^{* * *}$ \\
Non-financial crises & 1.724 & 1.656 & 1.967 \\
& $(11.648)^{* * *}$ & $(12.696)^{* * *}$ & $(11.335)^{* * *}$ \\
$\begin{array}{l}\text { Test for equality } \\
\begin{array}{l}\text { Financial crises - Non-financial } \\
\text { crises }=0\end{array}\end{array}$ & 3.105 & 2.987 & 3.370 \\
\hline
\end{tabular}

Note: *** indicates coefficient is significant at the $1 \%$ level. $t$-statistics are in parentheses. 
The results are similar to the findings presented in Table 3. Confirming the evidence in Choudhry et al. (2016), Ho et al. (2014), Rejeb and Salha (2013) and Schwert (1989, 2011), we find that financial crises have dramatic effect on the risk of stock. The findings signify that risk for all, Islamic and conventional stocks are significantly higher during the periods of financial crises than the periods of non-financial crises. For examples, the risk for all, Islamic and conventional stocks are $4.829(t$-statistic $=4.743), 4.643(t$-statistic $=4.402)$ and $5.337(t$ statistic $=5.252)$ respectively during financial crisis periods, and $1.724(t$-statistic $=11.648)$, $1.656(t$-statistic $=12.696)$ and $1.967(t$-statistic $=11.335)$ respectively during non-financial crisis periods. They all have statistically significant risk differences between the periods of financial crises and the periods of non-financial crises.

Moreover, risk from Islamic stocks is comparatively lower than conventional and all stocks during the financial crises. This is perhaps due to Islamic stocks exclude many interest-based financial institution stocks which suffer from considerable decrease in their stock prices during the financial crises. Moreover, Islamic markets are prohibited from holding sub-prime mortgage securities and derivatives and hence Islamic stocks enjoy the benefits of risk reduction and stability during the global financial crisis (Akhtar \& Jahromi 2017).

TABLE 5. Risk, financial crises and control variables

\begin{tabular}{lllllll}
\hline & \multicolumn{2}{c}{ All stocks } & \multicolumn{2}{c}{ Islamic stocks } & \multicolumn{2}{c}{ Conventional stocks } \\
\hline Constant & $1.724^{* * *}$ & $1.428^{* * *}$ & $1.656^{* * *}$ & $1.404^{* * *}$ & $1.967^{* * *}$ & $1.613^{* * *}$ \\
& $(11.648)$ & $(4.975)$ & $(12.696)$ & $(5.382)$ & $(11.335)$ & $(5.043)$ \\
Financial crises & $3.105^{* * *}$ & $3.354^{* * *}$ & $2.987^{* * *}$ & $3.088^{* * *}$ & $3.370^{* * *}$ & $3.839^{* * *}$ \\
& $(3.009)$ & $(3.027)$ & $(2.802)$ & $(2.858)$ & $(3.257)$ & $(3.277)$ \\
World market risk & & 0.094 & & 0.076 & & 0.110 \\
& & $(0.693)$ & & $(0.596)$ & & $(0.747)$ \\
Crude oil & & $0.016^{*}$ & & 0.013 & & $0.021^{*}$ \\
& & $(1.662)$ & & $(1.461)$ & & $(1.889)$ \\
Exchange rate & -0.062 & & -0.016 & & -0.125 \\
& & $(-0.827)$ & & $(-0.255)$ & & $(-1.337)$ \\
Inflation & & 0.389 & & 0.382 & & 0.501 \\
& & $(0.821)$ & & $(0.826)$ & & 0.012 \\
Industrial production & & 0.014 & & 0.014 & & $(0.578)$ \\
& & $(0.698)$ & & $(0.667)$ & & 0.256 \\
Adjusted R-squared & 0.232 & 0.249 & 0.246 & 0.251 & 0.214 & \\
F-statistic & $72.857^{* * *}$ & $14.137^{* * *}$ & $78.506^{* * *}$ & $14.275^{* * *}$ & $65.770^{* * *}$ & $14.648^{* * *}$ \\
\hline
\end{tabular}

Note: $* * *, * *$ and $*$ indicate coefficient is significant at the $1 \%, 5 \%$ and $10 \%$ levels. $t$-statistics are in parentheses.

Table 5 examines the impact of financial crises on the stock risk. The bivariate regression in columns 2, 4 and 6 suggests that financial crises increase stock risk for all, Islamic and conventional stocks. The findings are consistent with those of Ho et al. (2014) but contrary to Miniaoui at al. (2015). Once controlling for various variables known to have impact on risks, the effect of financial crises on stock risk remain significant as shown in columns 3, 5 and 7. Consistent with the results in Table 4, Islamic stocks experience the lowest risk during poor economic condition when measured by financial crises. 
TABLE 6. Risk, business cycles, financial crises and control variables

\begin{tabular}{llll}
\hline & All stocks & Islamic stocks & Conventional stocks \\
\hline Constant & $1.407^{* * *}$ & $1.386^{* * *}$ & $1.585^{* * *}$ \\
& $(7.106)$ & $(7.487)$ & $(7.142)$ \\
Contraction & $0.623^{*}$ & $0.523^{*}$ & $0.795^{* *}$ \\
& $(1.893)$ & $(1.700)$ & $(2.154)$ \\
Financial crises & $2.969^{* * *}$ & $2.764^{* * *}$ & $3.347^{* * *}$ \\
& $(6.682)$ & $(6.653)$ & $(6.718)$ \\
World market risk & 0.079 & 0.062 & 0.090 \\
& $(1.036)$ & $(0.878)$ & $(1.049)$ \\
Crude oil & $0.018^{*}$ & 0.014 & $0.023^{* *}$ \\
& $(1.825)$ & $(1.568)$ & $(2.097)$ \\
Exchange rate & -0.052 & -0.007 & $-0.112^{* * *}$ \\
& $(-1.367)$ & $(-0.196)$ & $(-2.650)$ \\
Inflation & 0.320 & 0.324 & 0.413 \\
Industrial production & $(1.225)$ & $(1.328)$ & $(1.409)$ \\
& 0.018 & 0.016 & 0.016 \\
Adjusted R-squared & $(0.878)$ & $(0.871)$ & $(0.725)$ \\
F-statistic & & & \\
\hline
\end{tabular}

Note: $* * * * *$ and $*$ indicate coefficient is significant at the $1 \%, 5 \%$ and $10 \%$ levels, respectively. $t$-statistics are in parentheses.

We also examine whether business cycles and financial crises have significant impact on stock risk when both variables are added in the same regression as shown in Equation (8). The regression results are tabulated in Table 6 . The results show a higher degree of stock risk during economic contraction and financial crises after including control variables. Similar to the previous results, compared to all stocks and conventional stocks, Islamic stocks tend to expose to the lowest level of risk during economic contraction and financial crises.

\section{IMPLICATION}

Overall, our findings shed some lights on the roles of business cycles and financial crises in influencing stock risks. The results provide implications for academics, investors and policymakers. This paper fills the gap in the literature regarding the significant impact of the business cycles and financial crises on stock risk in the context of Islamic and conventional stocks. The findings suggest that investors who prefer investment with lesser risk may consider Islamic stocks as a potential investment vehicle since Islamic stocks have lower risk compared to conventional stocks. In addition, the findings may have implication for policymakers on the importance of stabilising economic conditions as stock risk diminishes in good economic state. Policymakers should create effective policies to promote expansion in economy and reduce the probability of the occurrence of market crises. 


\section{CONCLUSION}

In this study, we explore the role of business cycles and financial crises which are expected to matter in affecting stock risks. Unlike most existing studies focus on conventional stocks, we use both Islamic and conventional stock data.

Using 1,283 firms in the Malaysian stock market from 1997 to 2016, we find evidence that there is a statistically significant relationship between stock risk and business cycles. We further divide the sample into Islamic and conventional stocks. Similar to all stocks, the findings show that the Islamic and conventional stocks tend to have higher risk, measured by the standard deviation, during economic contraction than during economic expansion. The findings of greater risk during economic contraction remain statistically significant after controlling for world stock market risk, crude oil price changes, exchange rate changes, inflation rates and industrial production growth rates. The results may be because of the occurrence of recession exacerbates the uncertainty about the process of producing future cash flows and discount rate.

Moreover, Islamic stocks exhibit lower risk as compared to conventional and all stocks. The findings may be due to Islamic stock market emphasizes on risk-sharing and ethical investment. Also, it is free from activities banned by Islam such as ambiguity, and hence Islamic stocks have lower uncertainty regarding the expected returns on the investments.

Further, we examine the relationship between financial crises and stock risk. We find remarkably consistent results. Specifically, the risk is higher in the periods of financial crises than in the periods of non-financial crises, after controlling for various variables known to have effect on risks. Finally, we add both business cycles and financial crises in the same regression model and the results show that both economic contraction and financial crises increases stock risks. Islamic stocks are exposed to lesser risk compared to the conventional and all stocks. This is probably because interest-based financial institution stocks which suffer from substantial decline in their stock prices during the financial crises are excluded from the Islamic stocks.

\section{ACKNOWLEDGEMENT}

We are thankful to the Universiti Kebangsaan Malaysia for funding the study under the Young Researcher Encouragement Grant (Geran Galakan Penyelidik Muda, GGPM-2017008).

\section{REFERENCES}

Ahmed, N. \& Farooq, O. 2018. Does the degree of Shari'ah compliance affect the volatility? Evidence from the MENA region. Research in International Business and Finance 45: $150-157$.

Akhtar, S.M. \& Jahromi, M. 2017. Impact of the global financial crisis on Islamic and conventional stocks and bonds. Accounting \& Finance 57(3): 623-655.

Al-Zoubi, H.A. \& Maghyereh, A.I. 2007. The relative risk performance of Islamic finance: A new guide to less risky investments. International Journal of Theoretical and Applied Finance 10(2): 235-249.

Alam, N. \& Rajjaque, M. 2010. Shariah-compliant equities: Empirical evaluation of performance in the European market during credit crunch. Journal of Financial Services Marketing 15: 228-240. 
Athukoralalage, I.K., Valadkhani, A. \& O'Brien, M. 2010. The effects of financial crises on international stock market volatility transmission. Economics Joint Scientific Conference: $1-25$.

Charles, A., Darne, O. \& Pop, A. 2015. Risk and ethical investment: Empirical evidence from Dow Jones Islamic indexes. Research in International Business and Finance 35: 33-56.

Choudhry, T., Papadimitriou, F.I. \& Shabi, S. 2016. Stock market volatility and business cycle: Evidence from linear and nonlinear causality tests. Journal of Banking and Finance 66: 89-101.

Cooper, M., Gutierrez, R. \& Hameed, A. 2004. Market states and momentum. Journal of Finance 59(3): 1345-1365.

Department of Statistics, Malaysia. 2017. Malaysian economic indicators: Leading, coincident and lagging index. Available at https://www.dosm.gov.my/v1/index.php? $r=$ column/cthemeByCat\&cat=82\&bul_id=RGp sUExnNU5FdVNvazFuK3BIRE9tZz09\&menu_id=YmJrMEFKT0p0WUIxbD1̄ibzZyd W9JQT09

Dewandaru, G., Bacha, O.I., Masih, A.M.M. \& Masih, R. 2015. Risk-return characteristics of Islamic equity indices: Multi-timescales analysis. Journal of Multinational Financial Management 29: 115-138.

Dharani, M. \& Natarajan P. 2011. Equanimity of risk and return relationship between Shariah index and general index in India. Journal of Economics and Behavioral Studies 2(5): 213-222.

Ho, C.S.F., Rahman, N.A.A., Yusuf, N.H.M \& Zamzamin, Z. 2014. Performance of global Islamic versus conventional share indices: International evidence. Pacific-Basin Finance Journal 28: 110-121.

Jawadi, F., Jawadi, N. \& Louhichi, W. 2014. Conventional and Islamic stock price performance: An empirical investigation. International Economics 137: 73-87.

Kew, S-R. \& Tee, L-T. 2018. Size, seasonality, market states and contrarian profits. Jurnal Pengurusan 52: 145-152.

Kose, M.A., Otrok, C. \& Prasad, E. 2012. Global business cycles: Convergence or decoupling? International Economic Review 53(2): 511-538.

Low, S-W., Tee, L-T. \& Kew, S-R. 2015. Does the quality of governance matter for equity market risk? Evidence from emerging and developed equity markets. Journal of Business Economics and Management 16(3): 660-674.

Mele, A. 2008. Understanding stock market volatility: A business cycle perspective. Working paper, London School of Economics.

Miniaoui, H., Syani, H. \& Chaibi, A. 2015. The impact of financial crisis on Islamic and conventional indices of the GCC countries. Journal of Applied Business Research 31(2): $357-370$.

Newey, W.K. \& West, K.D. 1987. A simple, positive semi-definite, heteroskedasticity and autocorrelation consistent covariance matrix. Econometrica 55(3): 703-708.

Rand, J. \& Tarp, F. 2002. Business cycles in developing countries: Are they different? World Development 30(12): 2071-2088.

Rejeb, A.B. \& Salha, O.B. 2013. Financial crises and emerging stock markets volatility: Do internal factors matter? Macroeconomics and Finance in Emerging Market Economies 6(1): 146-165.

Securities Commission Malaysia. 2016. List of Shariah-Compliant Securities by the Shariah Advisory Council of the Securities Commission Malaysia. Available at https://www.sc.com.my/wpcontent/uploads/eng/html/icm/sas/sc_syariahcompliant_1611 24.pdf 
Securities Commission Malaysia. 2018. Islamic capital market. Available at https://www.sc.com.my/general_section/islamic-capital-market/

Schwert, G.W. 1989. Business cycles, financial crises and stock volatility. National Bureau of Economic Research Working Paper No. 2957.

Schwert, G.W. 2011. Stock volatility during the recent financial crisis. National Bureau of Economic Research Working Paper No. W16976.

Lain-Tze Tee

Faculty of Economics and Management

Universiti Kebangsaan Malaysia

43600 UKM Bangi, Selangor, MALAYSIA.

E-Mail: jrtee@ukm.edu.my

Si-Roei Kew (corresponding author)

Faculty of Economics and Management

Universiti Kebangsaan Malaysia

43600 UKM Bangi, Selangor, MALAYSIA.

E-Mail: srkew@ukm.edu.my 